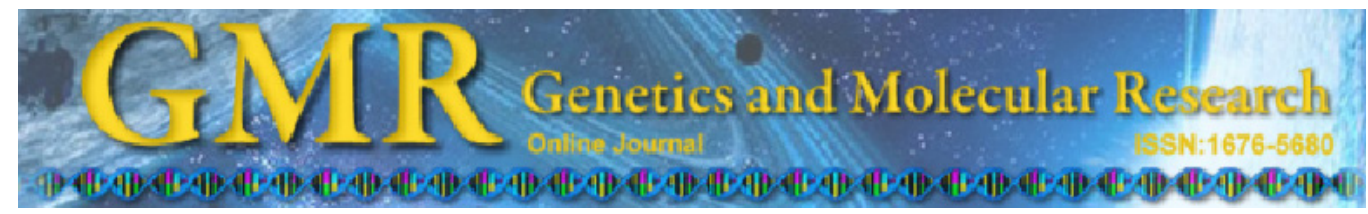

$\underline{\text { Short Communication }}$

\title{
Heterologous amplification and characterization of microsatellite markers in the Neotropical fish Leporinus friderici
}

\author{
A.M. Olivatti ${ }^{1}$, T.A. Boni ${ }^{1}$, N.J. Silva-Júnior ${ }^{2}$, L.V. Resende ${ }^{1}$, \\ F.O. Gouveia ${ }^{1}$ and M.P.C. Telles ${ }^{1}$ \\ ${ }^{1}$ Laboratório de Genética e Biodiversidade, \\ Instituto de Ciências Biológicas I, Universidade Federal de Goiás, \\ Goiânia, GO, Brasil \\ ${ }^{2}$ Mestrado em Ciências Ambientais e Saúde, \\ Pontifícia Universidade Católica de Goiás, Goiânia, GO, Brasil \\ Corresponding author: T.A. Boni \\ E-mail: talgeaiex@gmail.com
}

Genet. Mol. Res. 10 (3): 1403-1408 (2011)

Received August 17, 2010

Accepted April 3, 2011

Published July 12, 2011

DOI 10.4238/vol10-3gmr1020

\begin{abstract}
Leporinus friderici, native to the Amazon Basin and popularly known as "piau-três-pintas", has great ecological and economic importance; it is widely fished and consumed throughout much of tropical South America. Knowledge of the genetic diversity of this native species is important to support management and conservation programs. We evaluated microsatellite loci amplification, using heterologous primers, in 31 individuals of L. friderici. These samples were collected from natural populations of the Araguaia River basin, in central Brazil, and the DNA was extracted from samples of muscle tissue. Eight loci were successfully analyzed. Six of them were polymorphic, and the number of alleles ranged from three to 10 . Values of expected heterozygosities for these polymorphic loci ranged from 0.488 to 0.795 . Exclusion probability $(0.983)$, the identity probability
\end{abstract}


(0.000073), and the mean genetic diversity values were high, showing that these microsatellite markers are suitable for assessing the genetic variability of $L$. friderici populations. There is a growing interest in studies that evaluate the genetic variability of natural populations for various purposes, such as conservation. Here, we showed that a viable alternative to the costly development of specific primers for fish populations is simply testing for heterologous amplification of microsatellite markers available from research on other species.

Key words: SSR; Transferability; Genetic variability; Cross-amplification

\section{INTRODUCTION}

The fish Leporinus friderici, popularly known as "piau-três-pintas", belongs to the family Anastomidae and is endemic to South America. This fish species is native to the Amazon and La Plata Basins, commonly inhabits rivers, lakes and flooded areas, and feeds on insects, fruits and seeds (Nomura, 1984). In addition to the large ecological importance, $L$. friderici has a reasonable economic value both for commercial and sport fishing. However, this species shortly migrates throughout rivers, and thus, their populations are suffering declines due to the intense construction of dams in Brazil.

The genetic diversity of native species is an important feature to be considered in conservation and management programs. The use of molecular techniques to assess patterns of genetic variation has supported conservation programs, by indicating which species require greater conservation efforts and also by selecting areas where natural populations are viable (Johnson et al., 2001).

Recently, molecular markers have been commonly used in population studies. Simple sequence repeat (SSR) markers are preferable because they are potentially codominant and highly polymorphic. In addition, microsatellites have a wide distribution in the genome and can be efficiently identified, which is essential in studies about the genetic variability of populations (Collevatti et al., 1999). The polymorphism obtained with microsatellite markers has provided powerful information to be considered in the management of fish stocks (Alam and Islam, 2005), population analysis and biodiversity conservation (Romana-Eguia et al., 2004).

However, the use of microsatellite markers requires the development of specific primers, i.e., the unique sequences of DNA flanking SSR loci of a species' genome. Given that the development of primers can be costly, several studies have tested for possible heterologous amplifications in a target species using primers already described for evolutionarily related species (Cipriani et al., 1999; Brondani et al., 2003) or even for evolutionarily related genera (Zhan et al., 2009). Many studies have successfully demonstrated heterologous amplification (Barbosa et al., 2006; Hatanaka et al., 2006, Morelli et al., 2007), thereby lowering the costs of future projects. However, the loci detected by successful heterologous amplification should also be tested for their ability to access the polymorphism in the genome of the target species. Therefore, the aim of this study was to investigate the heterologous amplification of microsatellite loci developed for different fish species in $L$. friderici. 


\section{MATERIAL AND METHODS}

First, 46 SSR loci developed for several Neotropical ichthyofauna species were tested (Prochilodus argenteus, P. costatus, Leporinus macrocephalus, Astyanax fasciatus, and Poecilia reticulata). Of these, eight loci indicated successful heterologous amplification for the L. friderici genome. In the present study, we characterized these eight loci in 31 samples of L. friderici. These loci were originally developed for the following fish species: A. fasciatus (Ast09), L. macrocephalus (Lmac03, Lmac05, Lmac08, Lmac09), P. costatus (Pcos14, Pcos18), and P. argenteus (Par03) (Table 1).

DNA was extracted from samples of muscle tissue using the phenol-chloroform extraction protocol (Monesi et al., 1998). Total DNA of each individual was quantified and diluted to a final concentration of $5 \mathrm{ng} / \mu \mathrm{L}$. Each polymerase chain reaction (PCR) mixture consisted of $25 \mathrm{ng}$ DNA and $10 \mu \mathrm{L}$ of a solution containing autoclaved MilliQ water, $3.69 \mu \mathrm{M}$ primer, $13 \mathrm{mg}$ bovine serum albumin, $15 \mathrm{X}$ enzyme buffer, $12.5 \mathrm{mM} \mathrm{MgCl}, 250 \mu \mathrm{M}$ of each dNTP, and 1 U Taq-DNA polymerase (Phoneutria Biotechnology and Services Ltda.) in a final volume of $15 \mu \mathrm{L}$.

The amplification products were analyzed by electrophoresis on vertical $6 \%$, denaturing polyacrylamide gels using a molecular weight marker of $10 \mathrm{bp}\left(\right.$ Invitrogen $\left.^{\mathrm{TM}}\right)$. Gels were stained with silver nitrate for the visualization of alleles, following the method described by Creste et al. (2001).

Descriptive analyses of genetic variability of the loci were done using the genotypes obtained. The number of alleles per locus and observed and expected heterozygosities under Hardy-Weinberg equilibrium were estimated. These analyses and the test for deviation from Hardy-Weinberg expectations were performed with TFPGA 1.3 (Tools for Population Genetic Analyses) (Miller, 1997). We also estimated the probability of genetic identity (I) and paternity exclusion probability $(\mathrm{Q})$ for each polymorphic locus and overall loci, using the Identity 1.0 software (Wagner and Sefc, 1999).

\section{RESULTS AND DISCUSSION}

Two of the eight transferred loci were monomorphic (loci Pcos18 and Ast09), whereas the others were polymorphic. Considering the polymorphic loci, four were developed for $L$. macrocephalus (Lmac03, Lmac05, Lmac08, and Lmac09), one was developed for P. argentus

Table 1. Characteristics of the eight microsatellite loci successfully amplified for Leporinus friderici.

\begin{tabular}{|c|c|c|c|c|c|c|c|c|}
\hline Locus & $\mathrm{AT}$ & Size range (bp) & NA & Ho & $\mathrm{He}$ & Q & I & Reference \\
\hline Ast09 & 47 & 318 & 1 & - & - & - & - & Strecker, 2003 \\
\hline Lmac03 & 60 & $220-242$ & 9 & 0.433 & 0.680 & 0.491 & 0.166 & Morelli et al., 2007 \\
\hline Lmac05 & 66 & $228-252$ & 10 & 0.857 & 0.795 & 0.634 & 0.094 & Morelli et al., 2007 \\
\hline Lmac08 & 58 & $150-166$ & 8 & 0.541 & 0.751 & 0.534 & 0.175 & Morelli et al., 2007 \\
\hline Lmac09 & 60 & $173-182$ & 5 & 0.764 & 0.740 & 0.514 & 0.188 & Morelli et al., 2007 \\
\hline$P \cos 14$ & 62 & $127-136$ & 3 & 0.225 & 0.488 & 0.213 & 0.537 & Carvalho-Costa et al., 2006 \\
\hline$P \cos 18$ & 68 & 200 & 1 & - & - & - & - & Carvalho-Costa et al., 2006 \\
\hline Par03 & 62 & $290-320$ & 6 & 0.411 & 0.603 & 0.385 & 0.265 & Hatanaka et al., 2006 \\
\hline
\end{tabular}

$\mathrm{AT}=$ annealing temperature $\left({ }^{\circ} \mathrm{C}\right) ; \mathrm{NA}=$ number of observed alleles; Ho $=$ observed heterozygosity; $\mathrm{He}=$ expected heterozygosity; $\mathrm{Q}=$ paternity exclusion probability; I = identity probability. 
(Par03), and one was developed for P. costatus (Pcos14). It is interesting that polymorphism was observed for the loci developed for the genera Prochilodus. However, polymorphism was more consistently observed for the loci developed for all species belonging to the Leporinus genus, emphasizing that heterologous amplifications are successfully observed for evolutionarily related species (Cipriani et al., 1999; Brondani et al., 2003).

Annealing temperatures of amplified polymorphic loci ranged between $58^{\circ}$ and $66^{\circ} \mathrm{C}$, whereas size variation of alleles ranged between 127 and $320 \mathrm{bp}$. Allelic diversity across the six microsatellite loci ranged from three to 10 alleles/locus, totaling 41 alleles (Figure 1).

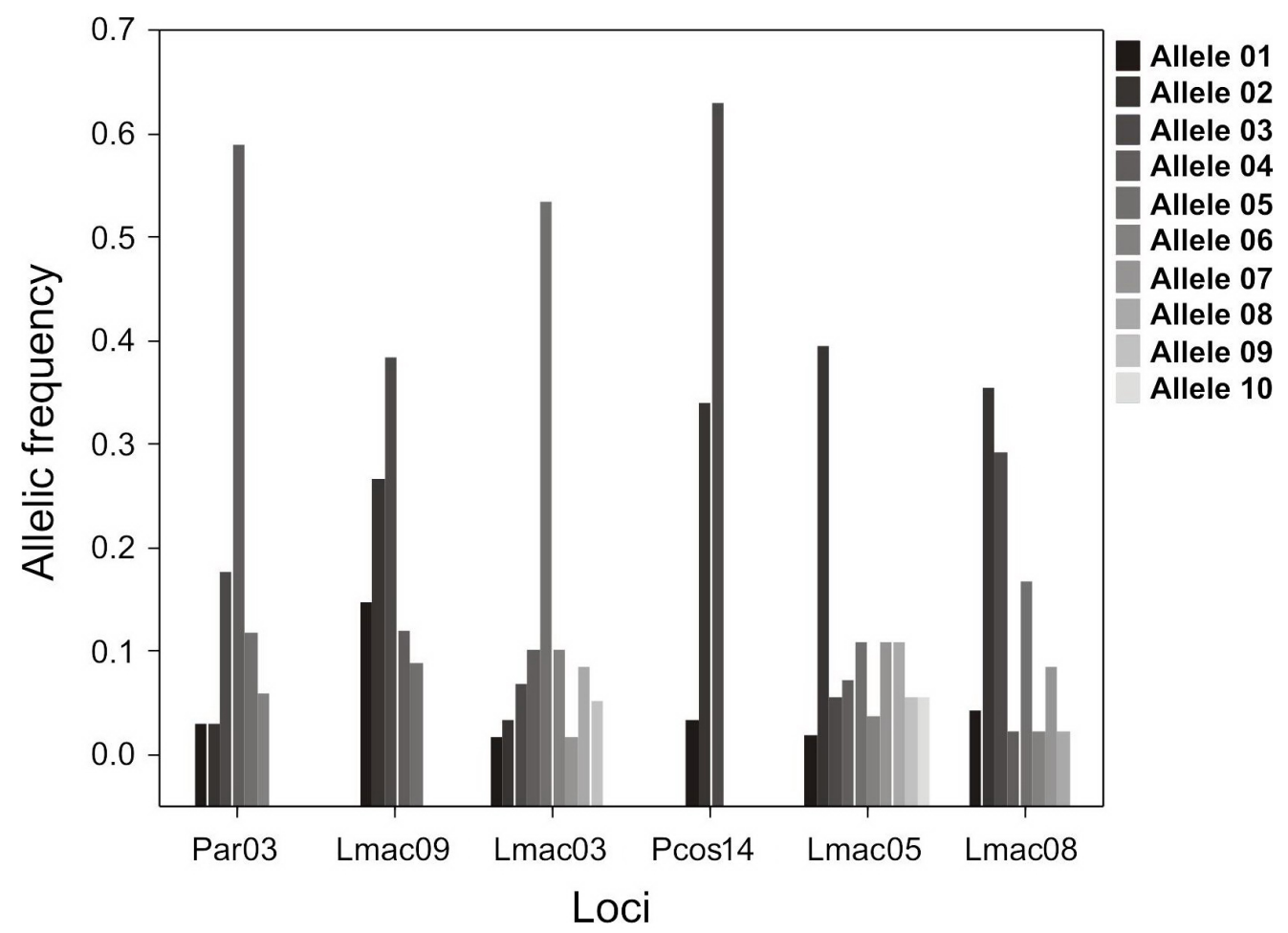

Figure 1. Allelic frequencies of the six polymorphic loci successfully transferred for the fish Leporinus friderici.

The average expected and observed heterozygosities across loci were 0.67 and 0.54 , respectively, and all loci were in Hardy-Weinberg equilibrium $(\mathrm{P}<0.05)$. As expected, higher values of heterozygozities were observed when primers developed for species of the genus Leporinus were tested, in comparison with those developed for other fish genera (Table 1). The mean genetic diversity value was 0.750 . The high values of heterozygosity and mean genetic diversity showed considerable variability among individuals. Paternity exclusion (Q) and identity (I) probabilities were 0.983 and 0.000073 , respectively. Therefore, the set of loci analyzed could be used for gene flow estimation in paternity analysis. The paternity exclusion probabilities across loci were NE-1P $=0.0133$ and NE-2P $=0.0013$ for all populations. The combined non-exclusion P(ID) was $3 \times 10^{-8}$. 
Molecular markers are useful tools in studies aiming to assess the genetic variability of natural fish populations, which could generate, for instance, important conclusions about the consequences of threats to natural populations, such as habitat fragmentation due to the construction of dams in Brazilian rivers. In fact, populations of migratory fish such as $L$. friderici are suffering declines in floodplain systems (Alves, 2006). Particularly, microsatellite markers successfully transferred for $L$. friderici could be efficiently used in studies focusing on the genetic variability of populations. To the best of our knowledge, there is no record in GenBank (see, www.ncbi.nlm.nih.gov) or in the literature about specific microsatellite primers developed for $L$. friderici. In accordance, studies on the genetic structure of populations of Neotropical fish are still scarce (Renno et al., 1991; Telles et al., 2010).

The development of microsatellite primers is costly and sometimes ineffective to detect polymorphism in natural populations (e.g., Telles et al., 2010). Therefore, the successful heterologous amplification observed here suggests that further studies on other species should focus on transferability as an alternative to find suitable and inexpensive primers that could be used to evaluate genetic variability in natural populations. Indeed, the six markers that were amenable to heterologous amplification in the fish L. friderici may be used in future programs of the management, monitoring and conservation of this species.

\section{ACKNOWLEDGMENTS}

Research supported by Systema Naturae Consultoria Ambiental Ltda. M.P.C. Telles and T.A. Boni have been continuously supported by CNPq grants.

\section{REFERENCES}

Alam S and Islam S (2005). Population genetic structure of Catla catla (Hamilton) revealed by microsatellite DNA markers. Aquaculture 246: 151-160.

Alves CBM (2006). Jaú (Zungaro jahu): um peixe mais ameaçado que os outros? Bol. Soc. Bras. Ictiologia 83: 4-5.

Barbosa ACDR, Corrêa TC, Galzerani F, Galetti-Júnior PM, et al. (2006). Thirteen polymorphic microsatellite loci in the Neotropical fish Prochilodus argenteus (Characiformes, Prochilodontidae). Mol. Ecol. Notes 6: 936-938.

Brondani C, Rangel PH, Borba TC and Brondani RP (2003). Transferability of microsatellite and sequence tagged site markers in Oryza species. Hereditas 138: 187-192.

Carvalho-Costa LF, Hatanaka T and Galetti PM (2006). Isolation and characterization of polymorphic microsatellite markers in the migratory freshwater fish Prochilodus costatus. Mol. Ecol. Notes 6: 818-819.

Cipriani G, Lot G, Huang WG, Marrazzo MT, et al. (1999). AC/GT and AG/CT microsatellite repeats in peach Prunus persica (L.) Batsch: isolation, characterization and cross-species amplification in Prunus. Theor. Appl. Genet. 99: $65-72$.

Collevatti RG, Brondani RV and Grattapaglia D (1999). Development and characterization of microsatellite markers for genetic analysis of a Brazilian endangered tree species Caryocar brasiliense. Heredity 83: 748-756.

Creste S, Tulmann Neto A and Figueira A (2001). Detection of single sequence repeat polymorphisms in denaturing polyacrylamide sequencing gels by silver staining. Plant Mol. Biol. Rep. 19: 299-306.

Hatanaka T, Henrique-Silva F and Galetti PM Jr (2006). Population substructuring in a migratory freshwater fish Prochilodus argenteus (Characiformes, Prochilodontidae) from the Sao Francisco River. Genetica 126: 153-159.

Johnson WE, Eizirick E, Roelke-Parker M and O’Brien SJ (2001). Applications of Genetic Concepts and Molecular Methods to Carnivore Conservation. In: Carnivore Conservation (Gittleman JL, Funk SM, MacDonald D and Wayne RK, eds.). University Press, The Zoological Society of London, Cambridge, 335-358.

Miller M (1997). Tools For Populations Genetic Analyses (TFPGA) 1.3: A Windows Program for Analyses of Allozyme and Molecular Population Genetic Data. Available at [http://www.ccg.unam.mx/ vinuesa/tlem09/docs/TFPGADOC. PDF]. Accessed July 2011.

Monesi N, Jacobs-Lorena M and Paçó-Larson ML (1998). The DNA puff gene BhC4-1 of Bradysia higida is specifically 
transcribed in early prepupal salivary glands of Drosophila melanogaster. Chromosoma 10: 559-569.

Morelli KA, Revaldaves E, Oliveira C and Foresti F (2007). Isolation and characterization of eight microsatellite loci in Leporinus macrocephalus (Characiformes: Anostomidae) and cross-species amplification. Mol. Ecol. Notes 7: 32-34. Nomura H (1984). Dicionário dos Peixes do Brasil. Editerra, Brasília.

Renno JE, Machordom A, Blanquer A and Boursot P (1991). Polymorphism of mitochondrial genes in populations of Leporinus friderici (Bloch, 1794): intraspecific structure and zoogeography of the Neotropical fish. Genetica 84: 137-142.

Romana-Eguia MRR, Ikeda M, Basiao ZU and Taniguchi N (2004). Genetic diversity in farmed Asian Nile and red hybrid tilapia stocks evaluated from microsatellite and mitochondrial DNA analysis. Aquaculture 236: 131-150.

Strecker U (2003). Polymorphic microsatellites isolated from the cave fish Astyanax fasciatus. Mol. Ecol. Notes 3: 150151.

Telles MP, Resende LV, Brondani RP, Collevatti RG, et al. (2010). Isolation and characterization of microsatellite markers in the armored catfish Hypostomus gymnorhynchus (Loricariidae). Genet. Mol. Res. 9: 1770-1774.

Wagner HW and Sefc KM (1999). Identity 1.0. Centre for Applied Genetics. University of Agricultural Sciences, Vienna.

Zhan A, Wang Y, Brown B and Wang H-P (2009). Isolation and characterization of novel microsatellite markers for yellow perch (Perca flavescens). Int. J. Mol. Sci. 10: 18-27. 